\title{
Developing a Computer Based Test Application to Measure Braille Literation Ability for Special Teacher
}

\author{
Safaruddin $^{1 *}$, Johandri Taufan ${ }^{2}$, Arisul Mahdi ${ }^{3}$, Intania $^{4}$, and Rahmahtri Silvia ${ }^{5}$ \\ ${ }^{12345}$ Universitas Negeri Padang, Indonesia \\ "Corresponding author. Email: safaruddin0366@fip.unp.ac.id
}

\begin{abstract}
This study aimed to develop an application that can be used to measure the literacy skills of special teacher in braille literacy. The method used research and development. This research was started from (1) collecting data and information; (2) planning; (3) development of product forms; (4) preliminary field testing; (5) product revisions; (6) operational field testing; (7) operational product revisions; 8) Dissemination. The result of this research was the creation of an application that can be used to measure the ability of special educators in braille literacy. This application can be used in all regular schools that have special teachers.
\end{abstract}

Keywords: Computer Based Test, Inclusion, Braille, Application

\section{INTRODUCTION}

Currently, there are very many inclusive schools that do not have teachers who are experts in braille. One of the reasons for the lack of literacy in braille is the lack of competence of teachers in public schools and special schools in understanding braille. The number of special schools in Padang city has reached 37 [1], and the number of inclusive schools is 187 [2] but, only a few people have mastered braille literacy. this is also the case in the United States, which has 98,817 public schools but only 152 people have National Certification in Literary Braille (NCLB) [3]. The impact is that only about $8.5 \%$ of the use of braille literacy in blind children [4] was us as their main reading media. One way that can be done to overcome this problem is to prepare prospective teachers to be able to have skills in providing braille literacy. The development of technology which is currently increasing rapidly causes all aspects to change, including in the world of education [5], [6] Researchers use computer-based assessments to assess student abilities. Many researchers argue that this CBA provides a reliable solution to get an accurate assessment with a complex level of a competency [7]. This computer- based test (CBT) is considered to be more effective and efficient when compared to the manual method (writing using a stylus and reglet) because it requires a longer time. However, the use of CBT did not have a significant difference when compared to writing using paper and pencil [8]. The development of $\mathrm{CBT}$ is expected to improve performance, structure, or learning systems so that they canbe used and can be of good use [9]. The results of this ability will be used as a basis for assessing the level of understanding of GPK in braille literacy. The form of questions on CBT is in the form of multiple choices consisting of braille and caution letters (normal letters). The test that was administered took 48 minutes to identify the braille letters. while in other studies not only braille letters but also numbers, punctuation symbols, composition marks, and contraction for common words and letter combinations (a total of 254 questions).

\section{METHOD}

The method used in this research was research and development. Research develops processes in developing a computer-based test application. We used expert judgment invalidating the developed application.

\section{DISCUSSION}

\subsection{Braille}

Braille is one of the ways used by blind children in understanding literacy based on touch. The problem of blind children with visual problems makes blind children have to use other senses as a way to absorb information. Braille is not a separate language from Indonesian but rather a code in the form of raised dots transcribed into Indonesian. Braille code can be generated through six raised dots that can represent the letter $\mathrm{a}-\mathrm{z}$, count operations, punctuation, numbers, and others.

\subsection{Use of Braille}

Braille letters use a system of raised dots with three horizontal and three vertical positions. To make it easier to read and write braille, the raised dots are 
numbered from one to six. There are differences in how to write and read Braille. we can observe it based on the numbering used at these points. The numbering aims to make it easier for us to write and read braille. At the time of writing, positions one to three are on the right. However, at the time of writing, the numbers one to three are on the right.

\subsection{Computer Based Test}

Based on a survey conducted in the US it found that $80 \%$ of health and higher education schools use CBT. CBT has several important advantages when compared to testing using a Paper Based Test (PBT) such as time efficiency, direct assessment, and feedback in multiple-choice exam questions. Computers and related technologies can provide powerful tools to meet the new challenges of designing and implementing assessment methods that go beyond conventional practice and facilitate recording a broader list of cognitive skills and knowledge. PBT testing can be a lengthy and difficult administration when compared to CBT testing.

\subsection{Braille Test Application Development}

Fig. 1 displayed the front view of the developed application. When we open the application on Android, the initial screen will appear. Figure 2 displayed a menu that can be selected by the user. Based on the menu, users can customize the test to be used. Figure 3 displayed the score of the answers that have been done. Every incoming data will be processed and made as an indicator of basic braille questions and general knowledge, using the Adobe Flash Professional CS 6 application and Action Script 3.0 with Adobe AIR support for the Android Platform which is effective and efficient as a medium in testing the abilities of teachers for knowledge of Braille. This application was made with a question data design that has been validated by the validator. The problem in this application consists of 3 levels, namely basic braille, basic mathematics, and general knowledge. So, teachers who test through this application will first start with basic braille in which there are 4 more categories, namely alphabets, numbers, punctuation, and number operation signs. After the teacher has successfully worked on all the questions, the score will immediately come out to ensure knowledge.

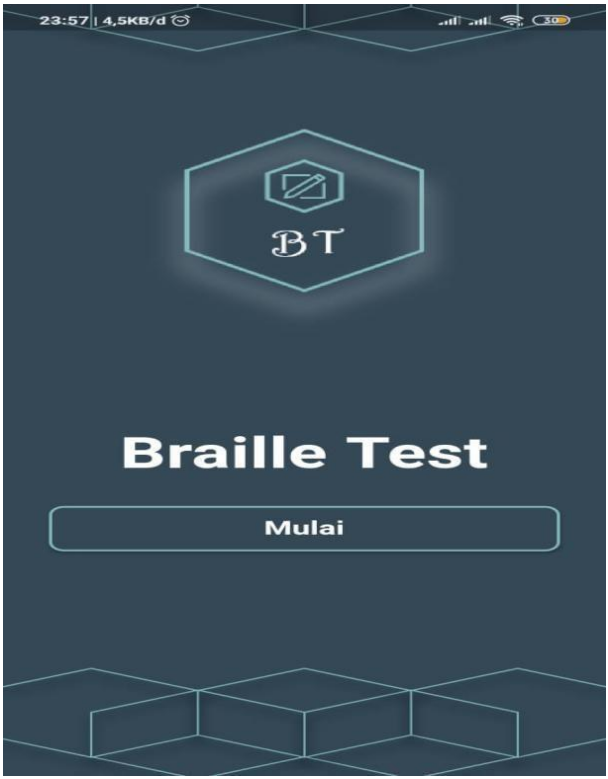

Figure 1. Braille Test application start menu

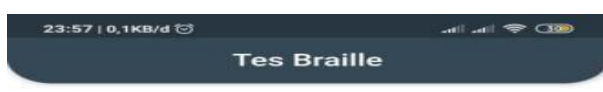

Selamat Datang intan

Pilih Kategori

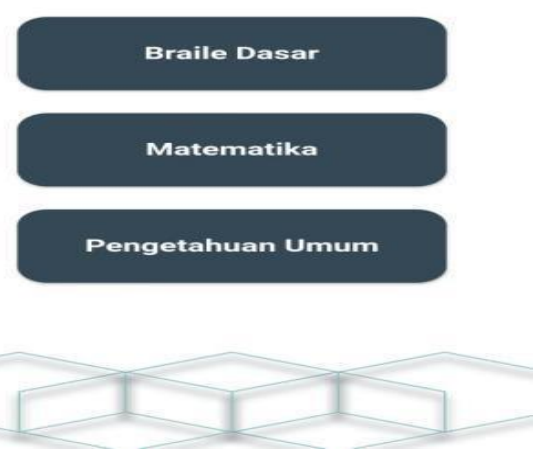

Figure. 2 Category menu

Each participant will start testing their understanding of braille literacy based on the existing category menu. because of that, the participants should start from the initial stage with the easiest category. 


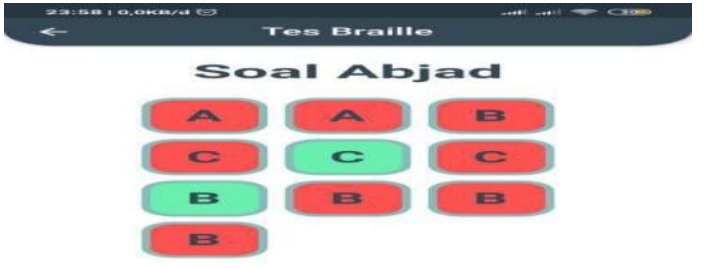

Skor Anda

20

. Figure 3. Menu display questions and total score

In this menu, a red box indicates the participant's answer was wrong and only able to answer 2 questions correctly so that they get a score of 20 .

\section{CONCLUSION}

Research conducted on the development of a computer-based test application to measure braille literacy skills for special educator teachers in inclusive schools in the city of Padang. This study developed applications that are more focused on testing the ability of teachers to use CBT-based applications in measuring teachers' understanding of braille literacy. The application that has been made than carried out a validation test so that the results of the application obtained can have maximum quality so that it can be useful for GPL in inclusive schools and special schools in providing braille material lessons to blind children. This research was carried out based on the problem of the low understanding of GPK and teachers who hold blind children towards braille literacy because so far the abilities of the teachers have not been tested validly.

\section{REFERENCES}

[1] Dinas Pendidikan Kota Padang, "Data SDLB DINAS PENDIDIKAN." [Online]. Available: http://diknas-

padang.org/mod.php?mod=sekolah\&op=sek\&kat= SDLB. [Accessed: 29-Feb-2020].

[2] M. Oktawina, "187 Sekolah di Kota Padang Selenggarakan Pendidikan Inklusif," 2019. [Online]. Available: http://rri.co.id/padang/post/berita/746556/daerah/18 7_sekolah_di_kota_padang_s elenggarakan_pendidikan_inklusif.html. [Accessed: 29-Feb-2020].

[3] National Federation of the Blind, "How many children in America are not taught to read?," 2013.
[Online]. Available: https://nfb.org/brailleinitiative.

[4] A. P. H. for the A. R. Blind, "Annual report 2014: Distribution of eligible students based on the federal quota census of January 7, 2013 (Fiscal Year 2014)."

[5] R. Kozma and A. R. E., "Qualitative case studies of innovative pedagogical practices using ICT," $J$. Comput. Assist. Learn., vol. 18, pp. 387-394, 2002.

[6] W. Pelgrum, "Obstacles to the integration of ICT in education: Results from a worldwide educational assessment," Comput. Educ., vol. 37, pp. 163-178, 2001.

[7] M. Naqeebul and K. Shaheen, "The Use of ICT for Assessment and Evaluation," vol. V, no. I, pp. 1728, 2019.

[8] M. Hosseini, M. J. Z. Abidin, and M. Baghdarnia, "Comparability of Test Results of Computer based Tests (CBT) and Paper and Pencil Tests (PPT) among English Language Learners in Iran," Procedia - Soc. Behav. Sci., vol. 98, pp. 659-667, 2014.

[9] O. Akdemir and A. Oguz, "Computer-based testing: An alternative for the assessment of Turkish undergraduate students," Comput. Educ., vol. 51, no. 3, pp. 1198-1204, 2008. 